\title{
THE MUSEUM, THE ORIGINAL EXPONENT OF VISUAL EDUCATION ${ }^{1}$
}

\author{
By Frank C. Baker. \\ University of Illinois.
}

We hear a great deal in these days about the value of visual education, and a society has been organized for the promotion of this method of teaching. This is indeed one of Nature's most effective methods of teaching her children the laws of the universe. It is said that we acquire much more information through the eye than through any other sense organ of the body. One often hears the expression "seein' is believin," which expresses this truth in a homely way.

The museums of science and art have been for many years pioneers in the field of visual education, bringing to the public, more or less imperfectly in the earlier years, the facts of Science and the beauties of Art. The museum is often called the "people's university," and it is quite true that the great majority of the population of our large cities acquire their only knowledge of the great world about them by visits to the museums, art galleries, and zoological gardens, where the fowls of the air, the beasts of the field, and the fishes of the sea, past and present, are gathered together in such an assemblage as Noah never dreamed of in his day and generation.

The value of the museum as an efficient aid in educational work is fully realized by but few educators. Even in many of the large cities there is little real cooperation between the local museum and the educational system, and this is by no means entirely the fault of the museum administrators. Visual education seems to center about pictures, lantern slides and moving pictures, and the aid that may be rendered by the museum exhibits is, in the main, unthought of. Perhaps many of our museums are to be held responsible for this condition, their exhibits being so often entirely useless to the teacher because of faulty installation, of value to the systematic student, but valueless to the general teacher. The cooperative association of school and museum in New York, Chicago, Milwaukee, and some other cities, augurs well-for the future of the museum in finding its true place in the educational system of the present age.

In a recent article on the "Contribution of Museums to Public School education," Mr. Peter A. Mortenson, Superintendent of Public Schools of Chicago, says: "The value of

${ }^{1}$ Contribution from the Museum of Natural History, University of Ill., No. 25. 
museum material as a factor in reinforcing school instruction has, no doubt, been recognized generally enough, but the difficulty lying in the way of its wider utilization has been the failure to find the museum material so organized that it would appeal to the dynamic interests of the children and at the same time portray the life that it was collected to represent." The larger museums, and even some of the smaller museums presided over by far-sighted curators, are removing this unfavorable criticism, and are preparing some of their exhibits to meet the requirements of the teacher of the grade school.

That the museum is also of value in reinforcing instruction in the universities and other higher institutions of learning seems equally certain, supplementing by the exhibits the material used in the classroom and laboratory; the larger value being in the coordination of all the material which may have been seen in the classroom only as isolated parts of the whole subject. This value of museum material has been recognized for many years and almost every college and university has its museum, even though it be a small one. Of late years some of the universities have drifted away from the use of the museum, hence the unsatis factory condition of much of the material in many university collections and the general poor opinion of most of such collections among museum men. I wish to indicate, briefty, some of the ways in which the museum may be useful in supplementing the general courses given in a university.

The modern teaching of geography consists not so much of political boundary lines, as of people, industries; natural reresources, and physical features. And here the museum can be of the greatest help in visualizing the text book. The cultures of people, how they utilize their natural resources and acquire material not found in their own country; the physical character of the country which has governed the development of the people-mountains, streams, valleys, deserts-all of these and more may be visualized in such a manner that the student easily grasps the significance of the facts of climate, topography, or geographic position, which have been potent in shaping the destiny of a group of peoples. The industries of certain countries may be shown, such as the common articles upon which we depend for our daily comfort- cotton and its derivities, iron and steel, pearl and ivory buttons, coal, aluminum, and many others. Exhibits showing the processes of manufacture from the collecting of the raw material to the selling of the finished 
product, with all of the by-products indicated, are of potent value to the teacher of geography.

And in the natural sciences-geology, zoology, botany-the museum is indispensable because it visualizes the courses given in the different branches. The student pursuing a course in systematic zoology may study the synoptic collection, arranged so that the major groups are exhibited to show their development from simple to complex organisms, their relation to each other and to the past history of the earth, the extinct groups being shown with the recent groups. Such an exhibit links together all life, showing it to be interrelated on every hand.

The student of geology may crystalize his course in historical geology or paleontology by consulting the exhibits of fossils, in which he may follow the changes of life from its first definite appearance in the early Cambrian seas to the latest prehistoric period. Here can be shown as nowhere else, the dying out of one type of life and the advent, almost instantaneously as it seems, of another. Such examples as the dying out of the Ammonites in the Cretaceous, the rise and fall of the huge saurians in Mesozoic times, and the advent of the mammals in Coenozoic times indicate the usefulness of such exhibits. The subject of coal can also be made more understandable by an exhibit of the peculiar flora of the Carboniferous. The evolution or descent of an animal and its modification during descent can be shown most effectively by groups arranged with specimens or restorations, supplemented by illustrations, so that the student grasps almost instinctively the significance of the subject. Such lines of descent as the horse, sloth, elephant, and armadillo can be very effectively shown.

Physiography naturally lends itself to the museum treatment and all phases of earth processes may be illustrated most effectively. The work of ice, snow, water, the sea, vulcanism, erosion, these and other subjects may be made clear by the use of properly constructed models of effective sizes.

The modern group idea has revolutionized museum exhibits. By this medium we are able to visualize the whole realm of nature, history and art. No longer must animals be seen only on shelves arranged in rows, like canned goods in a grocery; they may now be seen in their natural environment, in occupations such as they perform when unmolested by their arch-enemy, Man, the elaborateness and breadth of vision being limited only by the pocket book of the museum. In one museum may be 
seen the bird life of an island in the distant Pacific; in another, one may hunt the mountain sheep or the grizzly bear in the great mountains of the west; or visit a bird rookery in Florida or the islands of the West Indies. The fast disappearing native races of this and other continents may return and perform their ancient tribal ceremonies in the groups of the museum, which often appear so lifelike that one almost expects the wax effigy to breathe or to throw an upraised spear or stone through the glass of the case.

These groups need not be large or expensive. One of the most effective habitat groups in the museum of the University of Mllinois is in a case $5 \times 6 \times 2$ feet in which is shown an old decaying $\log$ with its characteristic animal life in the midst of a local environment, a small patch of almost virgin woodland near the university. An enlarged photographic background tinted, makes the old log appear to be in the woods, while spring flowers, birds, toads, and butterflies add to the naturalness of the exhibit. This group, including case and all accessories cost but $\$ 400$.

The modern study of natural history, now called ecology, may be very materially aided by these museum groups which visualize the life of different kinds of animal habitats, the natural homes of different species. Thus we may see the polar bear and musk ox of the Arctic, the deer and elk of temperate climes, and the gaudy birds of the tropics, all examples of the effect of climate on animal life. Pond life may be distinguished from river life, prairie life from forest life, all these may be shown in a museum group, surpassed only by the living animal in its real home. Often, two or more habitats may be shown in the same group for comparison, as a swampy, quiet pond behind a beach barrier, the animals of the quiet pond being strongly contrasted with the animals of the rougher water habitat of an exposed lake shore.

In the teaching of economic entomology, the museum is again a valuable aid. In small groups, insects injurious to certain plants may be shewn in their natural habitat on the plant as they would be seen when at work doing the injury, and the transformations may be shown so that the farmer or student may recognize the stage when the insect is most injurious. Such subjects as corn insects, grain insects, insects of the apple, pear, grape, garden insects, and many others may be shown as when living. These exhibits are far superior to the ancient custom of pinning the specimens in a glass covered tray, for the psychology of the group idea makes the insects seem more real. 
And in botany, exhibits are possible that will be an aid in the teaching of some branch of the subject. Forestry, extinct plants, evolution and descent of certain types, these and other subjects may be treated in museum exhibits.

These examples might be amplified indefinitely, but enough have been given to show that the museum is a potent agency in modern education, a fact that is, perhaps, not fully realized by educators in general. The museum is too often thought of as a storeroom or mausoleum in which musty specimens are stored away to be pored over by spectacled savants who live in a world by themselves. It is sadly true that this conception is not without foundation, for there are many museums in universities, colleges, normal schools, and academies, which are this and nothing else. But the modern museum is a vastly different thing, filled with objects potentially arranged, awaiting use by all progressive teachers.

In closing, may I use the words of one of England's greatest museum men, Sir William H. Flower, who says, "It is not the objects placed in a museum that constitute its value, so much as the method in which they are displayed and the use made of them for the purpose of instruction."

1Read before the Biology section of the Illihois State Academy of Science at Rookford, April 28, 1922.

\section{GETTING NEW STUFF ACROSS.}

Bx Henry Flury, Eastern High School, Washington, D. C.

This is a slangy title which $I$ have purposely chosen because it has a "straight from the shoulder" or businesslike ring to it. I see in my mind a clear picture of an earnest, clean-shaven man behind a long table, leaning over face to face with a customer, making a sale. He is "putting the deal across." That is what every good science teacher ought to be doing-- "selling" science to his pupils.

The methods of the salesman have something to commend them to the teacher. The salesman does not haul a load of merchandise up in front of his customer and then dump it there and ask for a bid. No, what he does first is to "create a desire" on the part of the prospective customer for the thing he is selling. Applying this to the teacher, he has one of the "best sellers" on the market if he knows how to put it across. How can this be done? 